\title{
PjBL-MOOCs As Future Models for Vocational High Schools
}

\author{
Mahfudi Sahly Subandi, Syarif Suhartadi, Partono, Andika Bagus Nur Rahma Putra \\ Universitas Negeri Malang
}

E-mail address: mahfudisahly@gmail.com

\begin{abstract}
The purpose of this research is to develop a Project Based Learning model assisted by the Massive Open Online Course. The research design uses Research and Development. The results of the feasibility study of PjBL-MOOCs products include: a) design of $93.75 \%$, b) manuals of $95.13 \%$, c) pictures and charts / charts of manuals of 92.31 , d) material of $85 \%$, e ) picture quality in material is $77.1 \%, \mathrm{f}$ ) video is $90.4 \%, \mathrm{~g}$ ) test instrument is $90.4 \%$, and $\mathrm{h}$ ) field trial results is $72 \%$. So that $\mathrm{PjBL}-\mathrm{MOOCs}$ are feasible to improve student learning outcomes.
\end{abstract}

Keywords: Project Based Learning, Massive Open Online Course, Vocational Education

Today, the world's technological advances have made very rapid progress known as the Industrial Revolution 4.0 era, without exception in the educational sector. A result of this industrial revolution is the emergence of various online learning sites or commonly known as Massive Open Online Courses (MOOCs). The development of MOOCs worldwide is very rapid (Shah, 2019). This gave rise to a new era in the world of education known as the era of education 4.0. However, many studies show various problems in the education system in Indonesia.

In reality, the standard of education in Indonesia is not in line with the evolution of educational technology. This fact occurs because in Indonesia, the education system has not functioned to the maximum. To Indonesia human growth from the educational perspective in the world's eyes still reveals lags This can be seen from the Human Development Index ( HDI) which explains how people can access development outcomes in earning income, health , and education. Indonesia's ranking is seen from the HDI score that lags behind those of other world countries (BPS, 2018). Meanwhile, technological advances require humans to adapt quickly to changing conditions, and in reality the market needs for quality labor often follow these advances in technology.

The curriculum is a key guide in the entire educational cycle, in order to increase the quality of learning, educational institutions and educators must be able to interpret those concepts. The efficacy of a learning process is largely determined by the human resources capacity (Lung-Guang, 2019).
Teachers should be able to take advantage of learning media that are sensitive to current student development, due to the influence of globalization, particularly technological development. Generation $\mathrm{Z}$ is an easy-to understand generation that is familiar with technology including the use of mobile phones, laptops, tablets etc. This generation is also also called pro gadget generation (Schenarts, 2019). Also, they spend more time on gadgets than studying. During this time students frequently use the internet for fun. The problem is that as many as $85 \%$ of students often use the Internet to access social media rather than to open textbooks. The sad reality at Vocational High Schools is that, in practice, the learning process is teacher-centered.

Students do not fully understand the knowledge provided by the teacher from the impact of the teacher-centered learning process. The problem that often arises during learning is that as many as $69 \%$ of students feel bored during the learning process because the teacher explains it too quickly. So that student activity does not occur as expected. Another problem when it comes to electric vehicle maintenance is that as many as 6 per cent of students understand the difficulties of the lesson because the teacher likes to get angry, 13 per cent of students feel that they have no practice, and 12 per cent of students feel that the teacher is not clear about delivering the material. This causes students to be busy on their own, sleeping in class, and talking to friends. Because many students anticipate learning media that are adapted to the current generation of learning. Problems in the educational process can be overcome by adapting a learning model for the teacher to match the students. One can say that 
project-based learning is the operationalization of the concept of production-based education developed at SMK (Choi, et al., 2019). As an institution serving to prepare graduates who are ready to work in the business and industrial world, vocational schools must be able to equip their students with the standardized skills needed for their work. Massive Open Online Course (MOOCs) is a global online learning, capable of accommodating large-scale student ability (Ortega-Arranz et al., 2019; Zhang et al., 2019).

It also explains that e-learning is one of the effective approaches to teaching and can help teachers by identifying teaching methods to make it easy for students to understand and help teachers perform regular and systematic teaching. Develop learning models integrated with technology and support programs for vocational revitalisation, namely PjBL-MOOCs (Project Based Learning with MOOCs). PjBL-MOOCs are a learning model that uses technology based on the Internet or is commonly called online learning (in networks). Using a project-based learning model in this learning model, where an educator can upload learning files in the form of learning videos, learning materials and student evaluations that can be done online. This learning model will also make learning independently easier for students and allow them to learn subject matter at any time and anywhere so that the learning process is not disrupted by time and place.

\section{METHOD}

\section{Research Design}

This work uses the R\&D (Research and Development) method. The research and development process reflects and relates to methodological measures suggested by experts on the Borg and Gall-adapted research and development model; Gall, Gall \& Borg; Richey and Klein; Peffers. Brand creation starts by creating marketing plans based on findings, questionnaires and interviews that are customized to the needs. In addition, researchers conducted an initial product development in the form of a sample product. The next step was an expert evaluation of the product being built by the researchers. Next the researchers performed a small group of initial product studies. Concretely, Figure 1 shows the phases of the work undertaken.

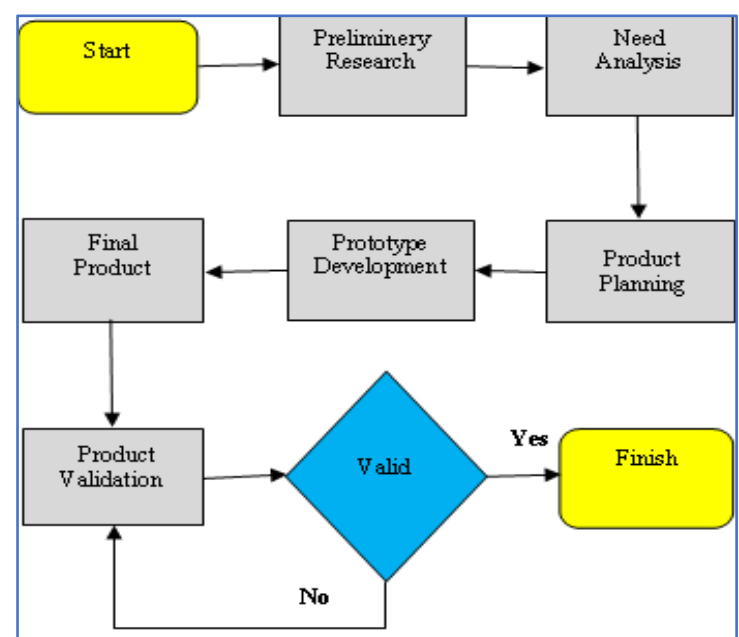

Figure 1. Research Stage

\section{RESULTS AND DISCUSSION}

\section{Results}

PjBL-MOOCs products include multiple product components including: 1) website of MOOCs, 2) product manuals 3) information on lighting system and instrument panel components, 4) learning videos on lighting system and instrument panel competencies, and 5) assessment tools. The online learning model is a website with the domain name https:/pjbl-moocs.com in the form of a MOOCs (Massive Open Online Course). The product developed is shown below in Figure 2.

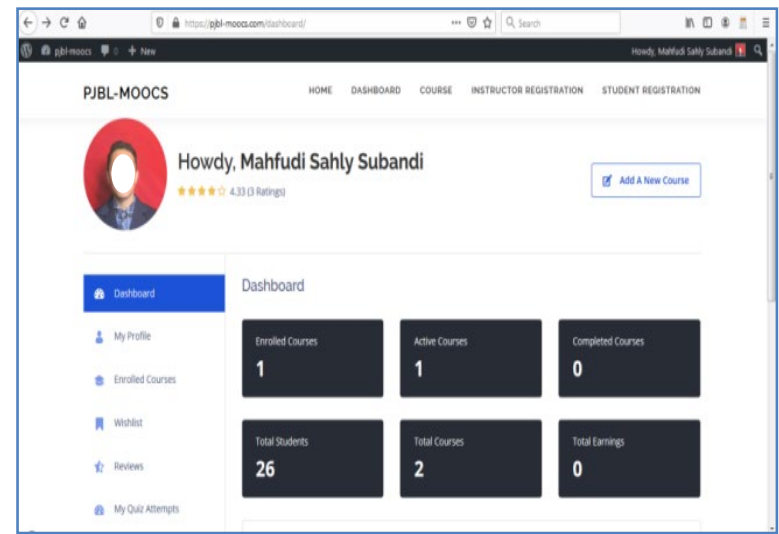

Figure 2. PjBL-MOOCs Product Development Results

The guidebook in the form of an electronic pdf book that is used as a complement to the product. Figure 3 below shows the complete built manual. 


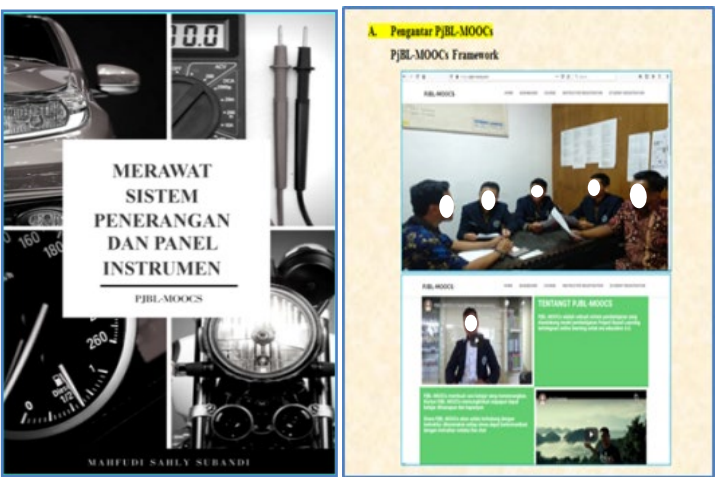

Figure 3. PjBL-MOOCs Product Guidebook

Teaching material in the form of material transcripts on the skills of the lighting system and instrument panel. Examples of information transcripts are shown in Figure 4 below regarding the lighting system and instrument panel.

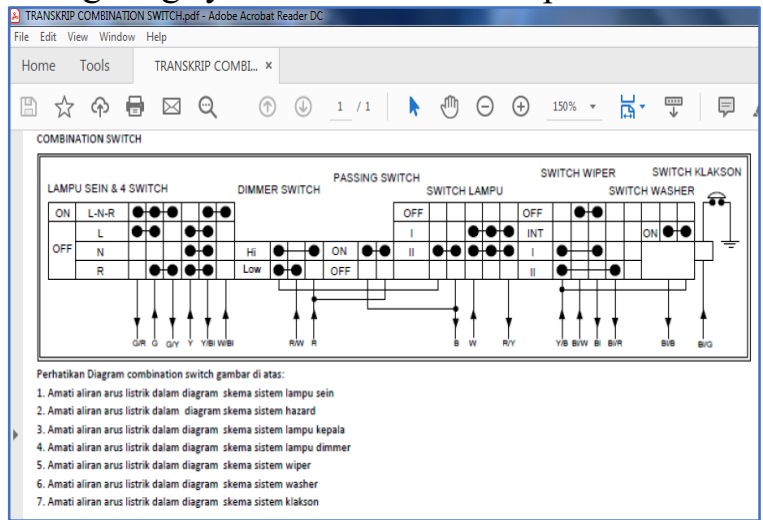

Figure 4. Information Transcripts

Training lessons on expertise in lighting device treatment and instrument stand. Examples of learning videos on the lighting system and instrument panel as shown in Figure 5.

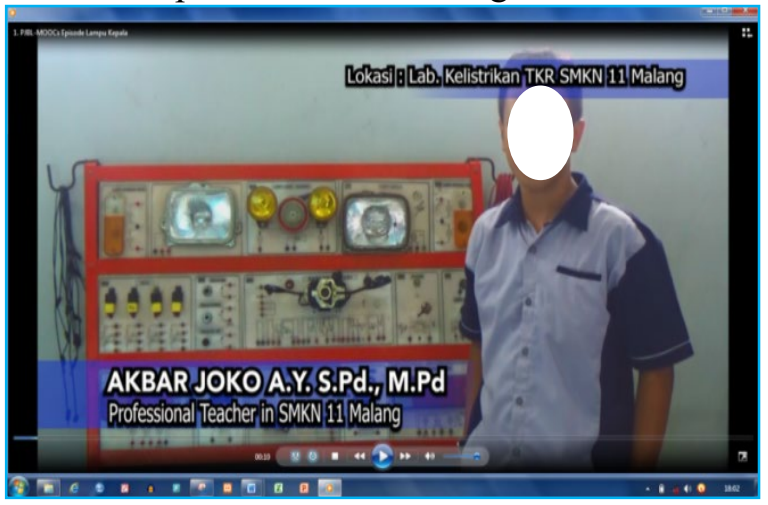

Figure 5 Product Components of PjBLMOOCs in the Form of Examples of Competency Learning Videos Caring for the Lighting System and Instrument Panel

The certificate for product PjBL-MOOCs is shown in Figure 6 below.

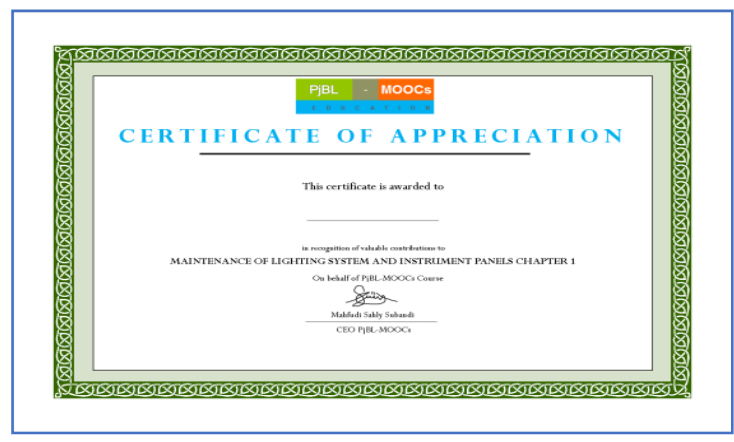

Figure 6. Certificate of Appreciation for Students who Complete a Competency Course Caring for the Information System and Instrument Panel

The standard of the expertly tested product is "Very Worthy." As in Figure 7, can be listed in detail below:

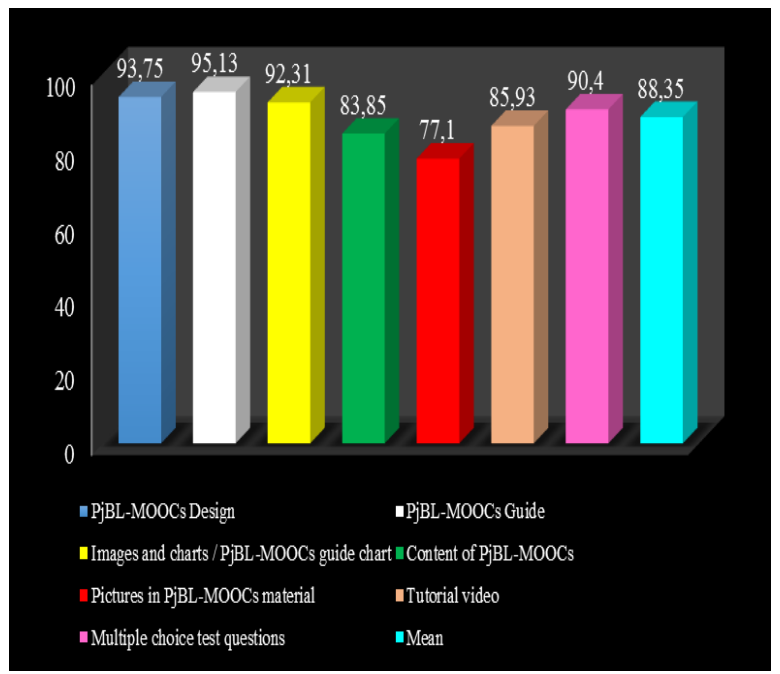

Figure 7. Conclusion of Expert Validation Results for PjBL-MOOCs

From the results of the trials classified as "Worthy" can be seen the product quality. One can illustrate the details as shown in Figure 8 below.

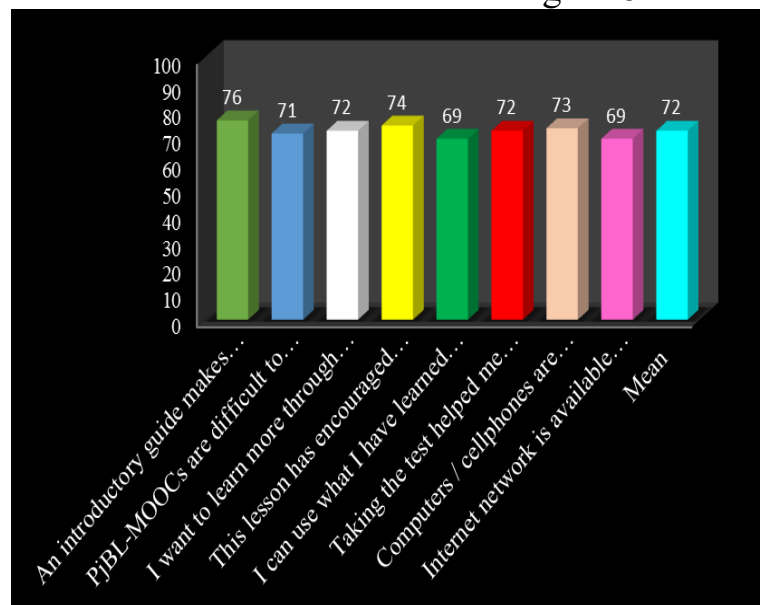

Figure 8. Conclusion of Prototype Product Test Results for PjBL-MOOCs 


\section{Discussion}

PjBL-MOOCs Innovation as Alternative Models

The PjBL-MOOCs innovation as an alternative learning model for era education 4.0 is very feasible in the process of integrating the role of technology in education. In this model, it is able to support students' cognitive by fulfilling all the facilities of the era education 4.0 learning model needs related to the learning strategy. PjBLMOOCs provide a variety of learning support features for the era of education 4.0 from planning, implementing and evaluating learning. The era of education 4.0 can be realized with this model because it includes learning quizzes, learning indicators, learning videos, etc. The role of the instructor in MOOCs is very important in monitoring student learning activities independently by providing feed back both internally and externally (Zhu \& Bonk, 2020). Giving feedback internally is closely related to students' cognitive and metacognitive. To facilitate students' cognitive learning processes, special strategies such as quizzes for selfevaluation, progress indicators, video tutorials, learning tips, navigation for courses are needed, and various other resources.

PjBL-MOOCs have fulfilled the requirements of developing MOOCs in the educational era 4.0. Product offerings are added to teaching materials that are easily developed. Utilization of MOOCs must be in line with the principle of media development in MOOCs on the suitability of the product to the learning objectives or competency targets to be achieved (Series, 2020; Loper, McNeill, González-Howard, MarcoBujosa, \& O'Dwyer, 2019). Other indicators in the development of MOOCs include the quality of teaching materials displayed systematically and supporting content in the form of images, graphics, videos, etc. Learning media in the form of MOOCs are focused on the presentation of material which directly impacts the learning outcomes in the form of changes in student behavior and knowledge both short and long term.

This product optimizes the needs of MOOCs in the education 4.0 era which emphasize meeting the unique needs of students. This is realized by optimizing the appearance of MOOCs that are adjusted to the characteristics like challenges in a gameOne of the main problems of MOOCs is the diversity of students related to the characteristics of learning styles and the level of knowledge and the need to personalize content and how to present it (Jung \& Lee, 2018; Qaffas, Kaabi, \& Shadiev, 2020).
The granting of free certificates in the PjBL-MOOCs course is intended to motivate students to complete courses that will later influence the student's learning experience. Courses that provide free certificates students register with higher verification than in the paid certificate path (Littenberg-tobias, Valiente, \& Reich, 2020). Of course this has an effect on access to free certificates associated with a lower level of certification, but overall the level of certification is higher, especially for those who take the course. In addition to the fact that costs are not required to obtain a verified certificate, student motivation can also increase in completing courses (Small, Deacon, Walji, Jaffer, \& Jawitz, 2019). This product as e-learning developed with easy and intersting design that supports the electronic learning process using media in the form of an integrated website face-to-face learning in class meet the validity criteria by e-learning experts. This is important to increase student interest in completing an online course. PjBLMOOCs are able to facilitate the education 4.0 needs that are closely linked to the online learning system without leaving the learning process in the classroom. This means that in terms of online learning PjBL-MOOCs that are designed face to face in class and online classes can also be called blended learning or hybrid learning. Students' interest in using e-learning media in the form of MOOCs is caused by MOOCs having to have an attractive and up-to-date appearance, because psychologically users will be more comfortable and eager to see the appearance of MOOCs that are interesting and in accordance with the latest developments.(Series, 2020).

Optimization of e-learning in PjBLMOOCs is adjusted to the needs of students in the disruptive era. This optimization is in the form of providing online quizzes whose evaluations are directly presented in the form of percentages and passing grades. The e-learning personalization strategy involves the students' role in deciding their own learning process, and also engages students in self-assessment to help develop selfreflective abilities (Qaffas et al., 2020).

The need for the importance of student involvement in creating a learning model in the era of education 4.0 can be met with the existence of PjBL-MOOCs. This product accommodate student participation in course improvement with the feature of giving advice and rating using students' ratings to instructors. This is adjusted to the profile of students who take the course. The design of MOOCs must be based on a curricular approach that is sustainable, social and 
communicative to meet participants' motivations and expectations (Orcid et al., 2020) .

$\mathrm{PjBl}-\mathrm{MOOCs}$ learning system as elearning system era education 4.0 is designed and determined based on changes in students' dynamic learning styles with the provision of full control content by students as well as providing criticisms and suggestions to instructors in order to adapt to student learning styles. The development of elearning in the era of education 4.0 needs to pay attention to the criteria of content development in an e-learning based on navigation support that provides students in an interactive and userfriendly learning environment (Mwambe \& Tan, 2020). Besides the learning system in e-learning must also be able to adjust the preferences of students. However, changes in the spontaneous learning style of students make it difficult to develop e-learning systems in terms of the integration of learning objects with learning styles in real time.

\section{Syntax of PJBL-MOOCs as a Learning Model in Vocational Schools}

Learning steps commonly called learning syntax in this case the syntax of PjBL-MOOCs as a learning model in vocational schools that integrates open online courses in learning is designed as a learning project in the form of online courses and classroom learning. The completion of the syntax of PjBL-MOOCs by teachers and students requires knowledge and creativity that continues to develop with the occurrence of a multi-directional interaction process between students and learning resources in order to create new meaning. Based on the results of expert validation the potential success of the learning syntax of PjBL-MOOCs to improve students' knowledge of cognitive aspects outlined in the sequence of learning and learning topics, and student activity in learning activities to achieve learning goals set with proven learning outcomes is very valid based on expert validation criteria set.

The syntax of the PjBL-MOOCs learning model adapted from the syntax of the project based learning model integrated with MOOCs is designed and specified in Figure 9.

In Figure 9 shows that the PjBL-MOOC learning syntax model consists of ten main stages. At each stage of the activities carried out by teachers and students. Several steps shall be taken at each meeting as described in Table 2.4 above. For example, the first stage is at meetings 1, 4, 7,
10 and 13. The PjBL-MOOC syntax consists of 16 meetings in one full semester. This will be explained, for example, at the first meeting, in three stages, namely: stage 1 , stage 6 and stage 7 . In stage 1 , the teacher's face-to-face class explains the Learning Implementation Plan (RPP), conducts an initial exam to measure students' initial skills, explains to students how to form groups. In the meantime, Stage 1 students understand the Learning Implementation Plan, answer questions and fill out questionnaires provided by the teacher, and form project assignment groups. Following stage 6 in the form of MOOCs, the teacher learns about the materials studied on the MOOCs website and the teacher prepares the materials and quizzes on the MOOCs website.

In the meantime, students in stage 6 are working on a quiz about the material they have studied with the MOOCs website within a specified time period. After stage 6, stage 7 development, the teacher facilitates discussion and student questions in the MOOC. In the meantime, students in stage 7 are listening online by posting comments on the teachers' MOOCs and asking questions about the problems that arise. This exposure is the most recent implementation of the SMK one-semester learning model of PjBLMOOCs, particularly in the field of Light Vehicle Electrical Maintenance. The syntax of the PjBLMOOCs learning model is able to integrate class learning with online learning, so that the interaction between students in this case students and relevant and structured learning resources can run optimally. The syntax of the PjBL-MOOCs learning model also supports optimal learning experiences related to the interaction between students in this case students with various learning resources.

Learning by design sources in this case are in the form of teachers, PjBL-MOOCs integrated learning modules, PjBL-MOOCs integrated learning videos, and learning strategies or methods using the PjBL-MOOCs website which are deliberately designed to support the achievement of learning objectives. Learning resources by utilization in this case instructors from senior students and from industry who informally participate in delivering the material, this learning resource is in the background of the community who participate in supporting the achievement of specified learning goals. 


\section{SYNTAX OF PjBL-MOOCs LEARNING MODEL}

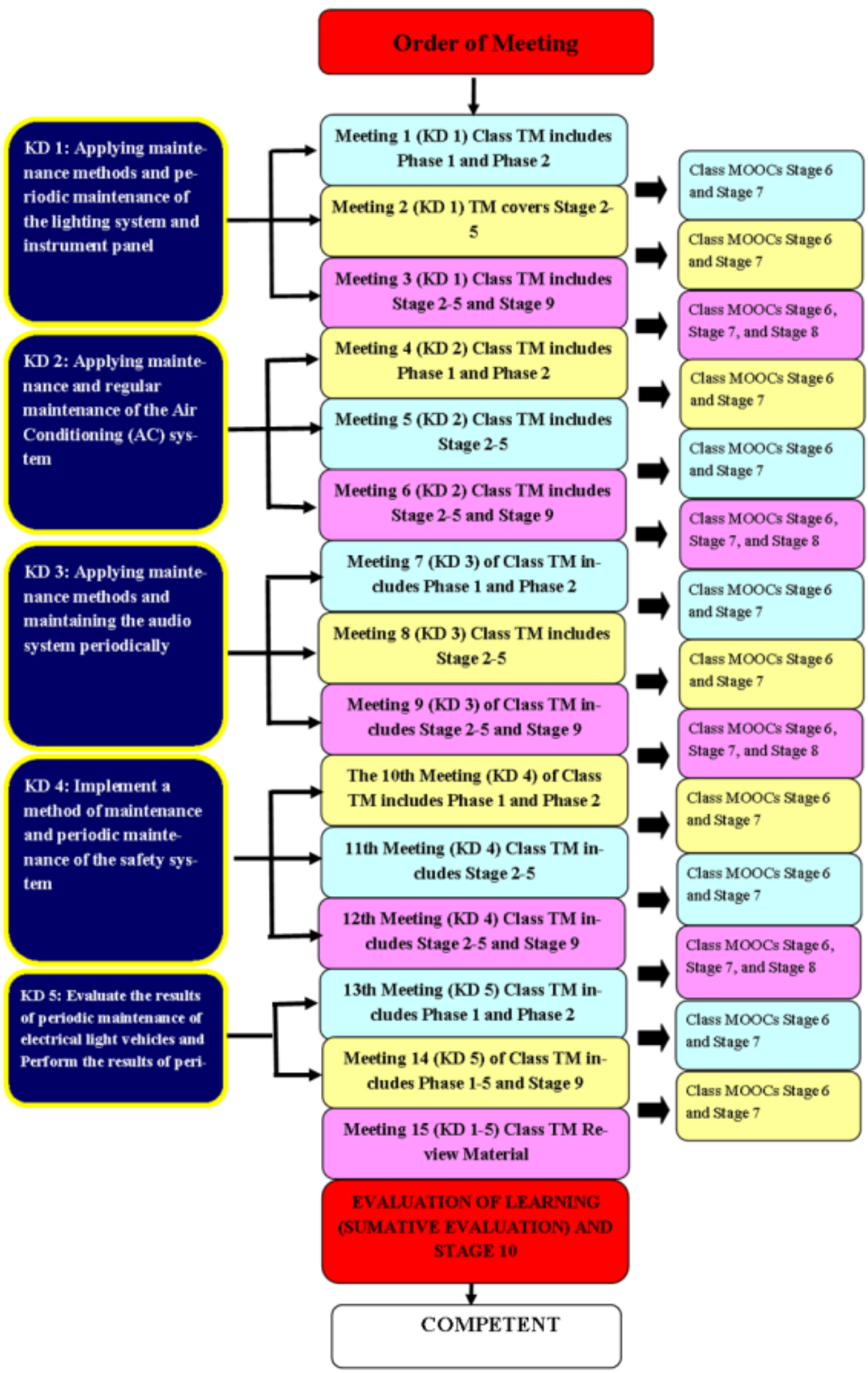

Figure 9. Syntax PjBL-MOOCs 


\section{CONCLUSION}

Created an online learning model development product in the form of distance learning technology to overcome the problems of the education system, especially in the competence of automotive light vehicle engineering expertise in SMKN 11 Malang, the product can be accessed via the website https://pjbl-moocs.com. The PjBL-MOOCs (Project Based Learning with Massive Open Online Course) learning model meets the feasibility aspects according to expert justification. Integrated learning model PjBLMOOCs (Project Based Learning with Massive Open Online Course) can be shown to be able to improve student learning outcomes based on the results of the product studies. The results of research and development of PjBL-MOOCs products show several product advantages including: a) learning models using MOOCs that are adapted to the project based learning model in the era of education 4.0 where educational management processes related to planning, implementation, and evaluation can be carried out as effectively and efficiently as possible. b) $\mathrm{PjBL}$ MOOCs supporting content is very user friendly because it is packaged on the basis of a game where there are challenges to learning levels, c) there is a feature of providing feedback and assessment by vocational students to instructors for adjusting courses according to student needs, d) PjBL-MOOCs make it easier for teachers to make courses because they only require the ability to drag and drop without complex coding, e) multiple instructors allow anyone to be an instructor on specified conditions, this allows for collaborative learning by instructors from industry professionals as well as from education practitioners and teachers work together to create courses that are interesting and in accordance with the era of education 4.0, f) students' forums in PjBL-MOOCs allow students to ask questions to instructors related to the learning problems encountered. The syntax of the learning model using PjBL-MOOCs is adapted from the syntax of the project based learning model that is integrated with online learning in the form of MOOCs. This integration has the potential to improve student learning outcomes. The syntax of the PjBLMOOCs learning model for each basic competency in SMK is designed with 3 face-toface meetings in class and 3 meetings in online classes.

\section{REFERENCES}

BPS Indonesia. (2018). Indeks Pembangunan Manusia 2017. Badan Pusat Statistik.

Choi, J., Lee, J. H., \& Kim, B. (2019). How does learner-centered education affect teacher selfefficacy? The case of project-based learning in Korea. Teaching and Teacher Education, 85, 45-57.

https://doi.org/10.1016/j.tate.2019.05.005

Jung, Y., \& Lee, J. (2018). Learning Engagement and Persistence in Massive Open Online Courses (MOOCS). Computers and Education. https://doi.org/10.1016/j.compedu.2018.02.01 3

Littenberg-tobias, J., Valiente, J. R., \& Reich, J. (2020). Studying Learner Behavior in Online Courses With Free- Certificate Coupons : Results From Two Case Studies. 21(1), 1-22.

Loper, S., McNeill, K. L., González-Howard, M., Marco-Bujosa, L. M., \& O’Dwyer, L. M. (2019). The impact of multimedia educative curriculum materials (MECMs) on teachers' beliefs about scientific argumentation. Technology, Pedagogy and Education. https://doi.org/10.1080/1475939X.2019.1583 121

Lung-Guang, N. 2019. Decision-making determinants of students participating in MOOCs: Merging the theory of planned behavior and selfregulated learning model. Computers and Education, 134, 50-62. https://doi.org/10.1016/j.compedu.2019.02.00 4

Mwambe, O. O., \& Tan, P. X. (2020). education sciences Bioinformatics-Based Adaptive System towards Real-Time Dynamic Elearning Content Personalization.

Orcid, E. F., Santander, C., Orcid, C. R., Santander, C., Luis, J., Dominguez, B., ... Santander, C. (2020). WHO TAKES A MOOC ? PROFILE OF STUDENTS IN THE. (April), 0-3.

Ortega-Arranz, A., Bote-Lorenzo, M. L., AsensioPérez, J. I., Martínez-Monés, A., GómezSánchez, E., \& Dimitriadis, Y. (2019). To reward and beyond: Analyzing the effect of reward-based strategies in a MOOC. Computers \& Education, 142, 103639. https://doi.org/10.1016/j.compedu.2019.1036 39

Qaffas, A. A., Kaabi, K., \& Shadiev, R. (2020). Towards an optimal personalization strategy in MOOCs.

Schenarts, P. J. (2019). ARTICLE IN PRESS Now Arriving: Surgical Trainees From Generation Z. Journal of Surgical Education. https://doi.org/10.1016/j.jsurg.2019.09.004

Series, C. (2020). Development of MOOCs synchronized life-based learning to improve the quality of outcomes in prospective vocational teachers in the era of Development of MOOCs synchronized life-based learning 
72 JURNAL PENDIDIKAN DAN PEMBELAJARAN, VOLUME 27-ISSUE 2, OKTOBER 2020

to improve the quality of outcomes in prospective vocational te. $0-7$. https://doi.org/10.1088/17426596/1456/1/012051

Shah, D. (2019). Online Degrees Slowdown: A Review of MOOC Stats and Trends in 2019 - Class Central.

Small, J., Deacon, A., Walji, S., Jaffer, T., \& Jawitz, J. (2019). Building capabilities : Using MOOCs to make transitions in work. 11(4), 427-441.
Zhang, H., Song, Z., Sun, M., Tang, J., Wang, X., \& Sun, J. (2019). Smart jump: Automated navigation suggestion for videos in MOOCs. 26th International World Wide Web Conference 2017, WWW 2017 Companion. https://doi.org/10.1145/3041021.3054166

Zhu, M., \& Bonk, C. J. (2020). Technology Tools and Instructional Strategies for Designing and Delivering MOOCs to Facilitate Selfmonitoring of Learners. 7(1), 31-45. 